Literature

ӘАәбият

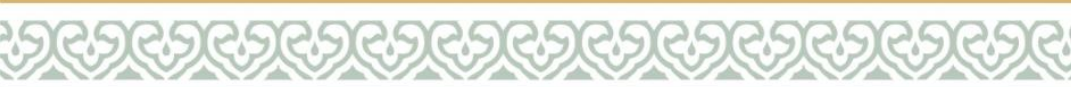

Аитература

DOI: $10.26907 / 2311-2042-2021-16-1-36-50$

\title{
THE DIALOGUE BETWEEN KARAKALPAK AND TATAR CULTURES IN THE WORKS BY T. ZHUMAMURATOV AND R. MINNULLIN
}

\author{
Malika Tleubergenovna Dzhumamuratova, \\ Karakalpak State University named after Berdakh, \\ 1 Ch. Abdirova Str., Nukus, 230100, Republic of Karakalpakstan, Uzbekistan, \\ djuma2008@mail.ru.
}

\begin{abstract}
The article systematizes the material on the history of the Karakalpak and Tatar poets' literary contacts. It has been proved that the common folklore heritage is the foundation for the literary connections between the two fraternal peoples. One of the incentives for its development is the readers' persistent interest in the literature of the Karakalpak and Tatar peoples. Translations of the works also play a huge part in strengthening friendship between these peoples. The article analyzes the work by the contemporary poets Tleubergen Zhumamuratov (1915-1990) and Robert Minnullin (1948-2020). It reveals the originality of the Tatar and Karakalpak themes in their heritage.
\end{abstract}

Key words: Karakalpak literature, Tatar literature, literary contacts, literary connections, dialogue among cultures.

\section{Introduction}

According to the Karakalpak literary critic Kabul Maksetov, the roots of the literary connections between the Tatar and Karakalpak peoples should be sought in ancient times in the common folk heritage [Maksetov, p. 4]. Liron Khamidullin gives vivid examples to confirm this thesis in his article "Reducing the distance..." The spirit of the ancestors is revived in the lyrics of the song: "Идел илнең ишеге, Жаек - жирнең бишеге" ("Idel is the gateway of the country, Uralsk is the cradle of the Earth"). The lines from the "Idegei" dastan are inscribed in the memory of the fraternal peoples: “Атам кияү булган жсир, Анам килен булган жсир, Кендегемне кискән жсир. Тәмле суын эчкән жсир". - "This is the land where my father became a husband, / This is the land where my mother became a daughter-in-law, / This is the land where my umbilical cord was cut off, / Where I drank delicious water."

Liron Khamidullin believes that apart from the common folklore heritage the two fraternal peoples are brought together by their common history rooted in the era of the Golden Horde, the fact also noted by the Tatar ethnographer Marsel Akhmetzyanov in his works [Tatarstanda Karakalpakstan ədəbiiat həm səngate kөnnəre, p. 55]. 
The development of literary contacts is also motivated by Karakalpak readers' persistent interest in Tatar literature. Thanks to the Tatar newspapers, published in Kazan, Ufa, and Orenburg, Gabdulla Tukay's poems quickly gained popularity in Central Asia even before the revolution, and the poet became the common heritage of the Turkic peoples.

Karakalpak writers got familiarized with the gems of Russian and foreign literature at the beginning of the twentieth century thanks to the Tatar language and through Tatar literature. The poems by G. Tukay, Derdemend, S. Ramiev resonated with the spirit of Karakalpak readers. The idea of East and West synthesis penetrated into Karakalpak literature through the works of these poets [Minnegalieva, Mingazova, Dzhumamuratova, $\mathrm{p}$. 26].

L. Khamidullin notes that Tatar readers show interest in the works of the Karakalpak chichens (improvisers who sang and played musical instruments). Thus, to celebrate the 150th anniversary of the poet Berdakh (1827-1900), Bika Rakhimova translated several of his poems into the Tatar language [Berdakh]. The Tatar writer is happy to state that a lot is being done in Berdakh's homeland to eternalize his memory [Tatarstanda Karakalpakstan ədəbiiat həm səngate kennəre, p. 56].

Translations of the works by Tatar and Karakalpak writers played a huge role in strengthening literary connections. Thus, G. Tukay's poems were translated into the Karakalpak language only after the revolution. According to K. Maksetov, the publication of a collection of G. Tukay's poems in 1960 was a real cultural event in the life of the republic. Karakalpak poets and translators B. Ismailov, O. Khozhaniyazov and I. Yusupov translated about 90 works of the great Tatar poet [Maksetov, p. 4]. In his introductory article to the collection I. Yusupov admits that he considers himself the apprentice of G. Tukay, "the sun of Tatar poetry." First, he got acquainted with the works of the Tatar poet thanks to the collection of his poems published in 1938. The collection was edited by M. Jalil [Tukai, p. 6].

K. Maksetov notes that G. Tukay played a huge role in the formation of Seyfulgabit Mazhitov's personality, the writer who was born in the Kazan province, but happened to live among the Karakalpak people. Here he gained fame not only as an author, but also as an educator, a compiler of textbooks and educational literature for Karakalpak schools. It is known that S. Mazhitov was closely acquainted with the works of G. Tukay F. Amirk- han, K. Nasyri, G. Kamal, G. Ibragimov, G. Kulakhmetov, Sh. Kamal and M. Gafuri. The writer made a great contribution to the formation and development of national drama and theatre [Maksetov, p. 4]. L. Khamidullin emphasizes his role in the establishment of the national mass media. S. Mazhitov first published the handwritten journal “Кызыл мөгаллим" (“The Red Teacher"), later, in 1931, he created the literary journal "Хезмәт әдәбияты" ("Literature of Labour") [Tatarstan Karakalpakstan ədəbiiat həm səngate kennore, p. 58].

It is significant that the first amateur drama club in 1919-1920 was established thanks to a native of Kazan, Kasim Yamashev. The club's repertoire consisted of the plays by Tatar playwrights M. Faizi ("Galiyabanu”), K. Tinchurin ("Kazan Towel", "Blue Shawl"), Kh. Ibragimov ("Shoes"). This prompted the creation of a professional theatre troupe, which was soon formed from the students of the Pedagogical College in Turtkulla. It was headed by Zarif Kasyimov [Maksetov, p. 4].

The publication of a collection of poems by Musa Jalil "Zhyrlarym" ("Моабит дәптеринен”) in 1958 was translated into the Karakalpak language with a foreword by $\mathrm{T}$. Zhumamuratov, which was a great cultural event. In the book, a significant part was translated by T. Zhumamuratov and $\mathrm{O}$. Khozhaniyazov, besides there are translations by M. Kasymov, Kh. Tazhimuratov and K. Dosanova [Zhalil].

The Days of Literature and Art contributed a lot to the friendship between the two fraternal peoples. Many writers still cherish the memories of the Days of Literature and Art of the Tatar Autonomous Soviet Socialist Republic (TASSR) in Karakalpakstan, which took place on August 20-25, 1980. According to the unanimous opinion of literary critics, this event opened a new chapter in the history of the dialogue between Karakalpak and Tatar cultures. As part of this large-scale cultural event, some collections were published such as "Tatar Stories" (1980) [Татарские рассказы], "Poets of Tatarstan" (1980) [Tatar shaiyrlary] and a special issue of the journal "Әмиуддәрья" [Omiȳdəria], which published translations of Tatar poets and prose writers (1981). Karakalpak readers got the opportunity to become familiar with the works of many Tatar poets such as S. Khakim, H. Tufan, A. Erikei, Sh. Galiev, Z. Nuri, F. Karim, S. Suleimanov, I. Bayanov, R. Fayzullin, I. Yuzeev, A. Iskhak, Zulfat, G. Rakhim, R. Kharis, R. Minnullin, R. Gataullin, as well as G. Akhunov's prose [Omiȳdəria]. 
In 1980, the play by the famous Tatar playwright Tufan Minnullin "Әлдермештен Әлмендер" (directed by K. Abdreimova) was staged at the Karakalpak State Theatre. The performance was given a warm reception by the Karakalpak audience [Zhumamuratova, 1981, p. 4].

In 1981, the TASSR received guests from the fraternal republic. A special issue of the magazine "Kazan utlary" ("The Lights of Kazan") was published [Tatarstanda Karakalpakstan ədəbiiat həm səngate kennəre]. Right before the Days of Literature and Art of the Karakalpak people in Tatarstan, an anthology of poetic and prose works of Karakalpak writers "Aral dulkynnary" ("Waves of the Aral Sea") compiled by Liron Khamidullin was published [Aral dulkynnary].

Thanks to L. Khamidullin, Tatar readers got a rare opportunity to travel back in time to the period of the Soviet Karakalpak literature formation on the pages of the "Kazan utlary" ("The Lights of Kazan") journal in 1981 [Tatarstanda Karakalpakstan ədəbiiat həm səngate kennəre, pp. 55-59].

These cultural events were reflected in the works of the authors. Robert Minnullin wrote a cycle of poems "Қарақалпақстан әхеңлери" dedicated to Karakalpakstan [Minłnullin, қаrақаlpastan әхеңleri, p. 8-13]. Tleubergen Zhumamuratov immortalized his impressions of his trip to Kazan in his poem "Kazan Shekheri" [Zhumamuratov, 2005, p. 226].

The theme of cultural and literary relations between Tatarstan and Karakalpakstan has repeatedly attracted the attention of scholars ([Maksetov], [Bekbergenova], [Minnegalieva, Mingazova, Dzhumamuratova], [Zhumamuratova, 2018], etc.). The study of "the dialogue among cultures" does not imply an assessment of a particular culture, but aims to identify the features and originality of ethnic cultures by comparing them and revealing the uniqueness of each culture. The introduction of the dialogue as a value guiding the world to noble endeavours helps to expand the spiritual and moral aesthetic experience.

The subject of our research is the dialogue of the Karakalpak and Tatar cultures in the works by Tleubergen Zhumamuratov (1915-1990) and Robert Minnullin (1948-2020).

\section{Materials and methods}

The research is based on the works of $\mathrm{T}$. Zhumamuratov and R. Minnulin which touch upon the Tatar and Karakalpak themes. The study of these sources enables us to reveal the nature of the literary and cultural contacts between Tatar and Karakalpak writers in the second half of the twentieth century.

Our research is carried out according to the principles of the systemic and holistic analysis of the artistic structure, combining elements of historical and comparative methods.

\section{Discussion}

Tleubergen Zhumamuratov and Robert Minnullin are outstanding representatives of the national literature of the twentieth century.

Tleubergen Zhumamuratov (1915-1990) was the national poet of Karakalpakstan (1967), the national poet of Uzbekistan (1969), the laureate of the State Prize named after Berdakh. He was also awarded the Order of Friendship of Peoples and the Badge of Honour. T. Zhumamuratov was a poet-improviser, lyricist, philosopher, master of satire and humour, connoisseur of history and literature, translator, playwright, and a publicist. His encyclopaedic knowledge in the field of language, history and art was mentioned in a number of research papers [Pakhratdinov, p. 111].

Robert Minnullin (1948-2020) was a famous Tatar writer, public figure and politician, Honored Art Worker of the Republic of Tatarstan, Honored Worker of Culture of Bashkortostan, the laureate of the State Prizes of the Republic of Tatarstan named after G. Tukay, M. Jalil, A. Alish, Hans Christian Andersen International Literary Prize, the State Prize of the Republic of Bashkortostan named after M. Karim ([Sarchin], [Khabutdinova, 2008], [Khabutdinova, 2018], etc.).

T. Zhumamuratov inherited the rare gift of an improviser from the famous storytellers of the past. The poet preserved the traditions of folklore in modern times. His fame and his poetic skill ("aitys") spread far and wide in his homeland and far beyond its borders. The poet and orator was characterized by a peculiar manner of expressive reading. T. Zhumamuratov could recite even his longest works by heart. This was a new phenomenon in national literature.

T. Zhumamuratov was a native of Muynak, a child of the Aral Sea, where great classical poets such as Kunkhoja, Azhiniyaz, Berdakh and Ayapbergen spent their lives. His poetic talent was closely associated with the art of "baksy" (singers), "zhyrau" (storytellers), "kyssakhany" (readers of folk books in a singing voice), masters of "aitys" (witty people). The storyteller Ayapbergen was Tleubergen's mentor [Zhumamuratov, 1986, p. 3], 
whose national poetic tradition Theubergen continued.

Thanks to his phenomenal memory, $\mathrm{T}$. Zhumamuratov collected and published the cultural heritage of the past. The poet was a great connoisseur and tireless promoter of his mentors' works of art. T. Zhumamuratov helped folklorists to restore the gem of folk poetry. He was the author of critical articles on preserving and publishing original versions of poetic heritage. The poet skillfully played the dutar.

The idea of friendship and dialogue among cultures lies at the heart of his artistic thinking [Maksetov, 1987, p. 141]. In his central poem, the poet asserts the values of peace and friendship between peoples:

Oh, people, people! You must understand

That the human being was created only for peace.

Have you forgotten that even without war

The human being doesn't live long? [Zhumamuratov, 1984, p. 22.] (this translation into English is based on the Russian translation by A. Kanykin).

"The world was originally created for everyone!" is the slogan of the Karakalpak poet [Zhumamuratov, 2016, p.18]

"Kazan shekheri" ("City of Kazan") was the first T. Zhumamuratov's poem where the theme of friendship between the Tatar and Karakalpak peoples was raised:

\begin{tabular}{|l|l|}
\hline Сиз бенен бир тәғдир ме- & We share our destiny and \\
нен арымыз, & dignity, \\
Биз айтамыз тиллеримиз & We say we have a common \\
ортақ деп, & language, \\
Бизлер Әмиудәрья татар- & We are the Tatars of the \\
ларымыз, & Amu Darya, \\
Татарды да билдик & We consider Tatars to be \\
қарақалпақ деп & our Karakalpaks. \\
[Zhumamuratov, 2005, pp. & (here and hereinafter the \\
226-227]. & $\begin{array}{l}\text { interlinear translation is } \\
\text { done by M. D.) }\end{array}$ \\
& \multicolumn{2}{|l}{}
\end{tabular}

The poet uses the ethnonym "Tatars" to restore the age-old roots of friendship between the two fraternal peoples. "In the Middle Ages, the ancestors of the modern Karakalpaks and Tatars were closely related ethnically, politically, economically and culturally. This phenomenon <...> has been preserved in the genealogies of these two kindred peoples. For example, it is believed that in ancient times the name of Maiky-bi was at the head of the genealogy of the Karakalpak tribes or kins", M. Akhmetzyanov shares his observations in the book
“Татар шәжәрәләре" (“Tatar genealogies”) [Okhmətжаnov, p. 29].

The poet was digging into to the ancient times, when the ancestors of the Karakalpaks in the early historical period lived along the banks of the Edil (Volga) and the Zhaiyk (Ural), but, being subjected to constant enemy raids, they were forced to disperse around the world: "Едил қайда, ел қайда" ("Where is the Volga, and where is my homeland"). In this poem, the author yearns for his historical homeland, expressing the aspirations of his nomadic people.

T. Zhumamuratov notes that his idea of the Tatar capital was based on the works of ancient storytellers:

\begin{tabular}{|c|c|}
\hline $\begin{array}{l}\text { Жас күнимнен қатеремде } \\
\text { сақлаўлы, } \\
\text { Еситкеним жыршылар- } \\
\text { дың жырынан, } \\
\text { Шәхәрсең сен ел аўзында } \\
\text { мақтаўлы, } \\
\text { Тарийхларға гүўа болған } \\
\text { бурыннан. } \\
\text { [Zhumamuratov, 2005, p. } \\
\text { 226]. }\end{array}$ & $\begin{array}{l}\text { Lives from a young age in } \\
\text { my memory, } \\
\text { What I heard in the stories } \\
\text { of storytellers. } \\
\text { You are a city, praised by } \\
\text { the people, } \\
\text { A witness to the history of } \\
\text { ancient times. } \\
\text { (interlinear translation). }\end{array}$ \\
\hline
\end{tabular}

The poet sees Kazan as the city associated with the names of the great classics of Russian and Tatar literature: A. S. Pushkin, G. Tukai and M. Gorky. As you know, his development as a poet was deeply influenced by the creative work of the Tatar poet Gabdulla Tukay [Minnegalieva, Mingazova, Djumamuratova, p. 26]. Thanks to Tatar translations, the Karakalpak poet got familiarised with classical works of Russian and world literature, which was reflected in the analyzed poem:

\begin{tabular}{|l|l|}
\hline “Едил бойы - ескиликли & They say, “The banks of \\
ел”-дейди, & Edil are ancient peoples.” \\
Қәсийетли сыпатының & It has wide magical quali- \\
түри кең, & ties. \\
Ата-бабам Пушкин ме- & Pushkin and Gorky were \\
нен Горькийди, & studied by my ancestors \\
Үйренипти уллы Тоқай & in the language of Great \\
тилинен & Tukay. \\
[Zhumamuratov, 2005, p. & (interlinear translation). \\
226]. & \\
\hline
\end{tabular}

Studying the memories about $T$. Zhumamuratov, we found an indicative dialogue between the father and the daughter, which took place after his trip to Kazan: 
"Dad, dad, the city of Kazan, is it a big cauldron (kazan)? Did you immediately slip out of the plane into a large cauldron? Have you been boiled?

"No, daughter! Kazan is a city where poetry is boiling! I composed "Едил бойы - ескиликли ел дейди, Қәсийетли сыпатының түри көп” and moved on!.. То compose a lot!" [Zhumamuratova, 2015, p. 3].

Thus, the Tatar capital acquires poetic outlines in the creative consciousness of the Karakalpak poet. For T. Zhumamuratov, the Tatar capital was a cauldron (kazan) of poetry, a focus of creative energy.

The writer's archive testifies to the close contacts of the Karakalpak writer with his Tatar colleagues. Thus, for example, it contains the Letter of Gratitude from the Tatar Publishing House, a sign of gratitude for the writer's merits in the field of translation in promoting the work of Karakalpak and Tatar poets [Zhumamuratov, 2020]. The library of T. Zhumamuratov stores the books of Tatar writers, in particular, the collection of Tatar poems "Яшьлегем - Чаллы" ("Youth Naberezhnye Chelny") compiled by Ravil Lotfullin. The dedication inscription on the book is very indicative: "To the outstanding national poet of the Fatherland, poet-philosopher, poet-citizen, wonderful person and wonderful praiser of friendship and brotherhood between peoples, glorious son and one of the aksakals of our faithful friend - the Karakalpak people, Tleubergen aga Zhumamuratov, whose natural talent and wonderful works serve as an example of selfless service to the Motherland. Best wishes and respect, Chelny writers. June, 1981" [Iash'legem- Chally, 1979]. This is how the autographed collection of poems by Saifi Kudash was given to the Karakalpak poet by the author for his seventieth birthday [Kudash]. Letters, congratulatory telegrams and postcards are another evidence of the close contacts between T. Zhumamuratov with Tatar writers.

Our attention was attracted by T. Zhumamuratov's poem "Amid the Ocean" (1969-1971) [Zhumamuratov, 1986, p. 13], in which the poet praises the feat of the Tatar boy Askat. The plot of the work is based on real events. The poet was attracted by the story of the miraculous rescue of a barge and four sailors in the vastness of the Pacific Ocean.

The poem consists of four parts. Its chronotope absorbs not only the sea, but also the remote railway station Shentala, located in the Samara Oblast.

The poet skillfully uses the technique of contrast in the poem. In the beginning, T. Zhumamura- tov glorifies the majestic beauty of the ocean. The poet associates the vastness of the ocean with the vastness of the human soul. "Melodious waltz" covers the Pacific Ocean and matches its dead calm. However, a sudden hurricane destroys this idyllic harmony of man and nature.

The author of the poem praises the courage of the sailors of the barge, caught in the grip of a storm. The poet admires the heroism of the Tatar Askat who in the critical situation took control of the barge that broke the mooring. Askat's conviction becomes key for characterizing the heroes: "We guys are not grass/That is bending in the wind" [Zhumamuratov, 1984, p. 18]. During their wanderings in the open ocean, the sailors experienced hunger and cold, more than once they looked death in the face.

T. Zhumamuratov uses romantic colours when describing the battle between the man and the elements. The poet is humbled by the feat of four brave sailors, representatives of different nations. T. Zhumamuratov puts special emphasis on the Tatar sailor's competent actions which determine the fate of the crew and the barge. The hero emerges victorious from the battle with the elements.

The second storyline in the poem allows the readers to understand the origins of Askat's courage. The poet introduces us to the story of the devoted love of the sailor and Nasima. It was the love for his family and his beloved girl that allowed the Tatar guy to withstand the worst moments of the storm. The poet praises the sensitivity and devotion of Nasima. Together with Askat's parents, she went through a terrible period when there was no news from the sailors. T. Zhumamuratov resorts to the technique of parallelism when portraying the life of Nasima. The poet again exploits the motive of overcoming difficulties in life. In order to find out what had happened to her beloved, the girl overcomes a long way in winter bad weather. It is noteworthy that when creating courageous images of lovers the poet relies entirely on the potential of folk poetry. This is especially evident at the level of portrait characteristics as the girls is compared to a reed. In the poem, the motive of the prophetic dream plays an important role. The girl believes in a happy outcome. The sailors return home as heroes. Askat is met by his father, Rakhimzyan aby, who is proud of his son. T. Zhumamuratov's poem has become a real hymn to a man who has overcome the elements.

Thus, T. Zhumamuratov glorified not only the Tatar land, but also the outstanding representatives 
of the Tatar people. All this clearly testifies to the respectful attitude of the writer to the fraternal people and their culture.

We encounter the same reverent attitude when we get familiarized with the cycle of poems by the Tatar poet R. Minnullin "Каракалпак аһәннәре" ("Karakalpak melodies"), created under the impression of the Days of Literature and Art in Tatarstan and Karakalpakstan. In 2019, this cycle was translated into the Karakalpak language by the poet Medrail Turynmuratov [Miңnullin, 2007, pp. 8588]. In the preface to his translations, the Tatar writer recalls the journey of the Tatar delegation to Karakalpakstan with great warmth (1980) [Miynullin, 2019]. The cycle consists of 5 poems. It opens with the poem "Yс син, чәчәк!" ("Grow, flower!"), where, the motive of overcoming life's difficulties is also central like in T. Zhumamuratov's works. Admiring the flower that grew on a hot soil, the poet reflects on the life potential of a person who, by the will of fate, is forced to live in such harsh natural conditions. R. Minnullin comes to the conclusion:

\begin{tabular}{|l|l}
\hline «Үс син, чәчәк, & "Grow, flower, \\
Чүл - үзеңнең & After all, the desert \\
Туган жирең бит» & is your homeland” \\
[Мinңnullin, қаraқalpastan & (interlinear translation). \\
әхеңlere, p. 285]. & \\
\hline
\end{tabular}

As a result, the poem turns into a hymn of devoted love for the homeland. For the Tatar poet, hot and windy Karakalpak land embodies the eternity and symbolizes the age-old rootedness of man in his homeland.

The melody of a friendly dutar in the poem "Уйна, дутар!" ("Play, Dutar") connects the banks of the Amu Darya with the Volga. It turns into a visible reminder of the common Turkic culture. The Karakalpak song is spreading under the sky of Tatarstan, reminding of the age-old friendship between the two fraternal peoples [Minңnullin, Каraқalpastan әхеңlere, p. 286].

R. Minnullin feels great joy when fighters from Karakalpakstan come to Sabantuy ("Kunak egetler" ("Guys-guests")). The poet is sincerely proud of the national sport. He is immensely happy that the guests will try themselves in the Tatar martial art. The image of a white embroidered towel in the poem not only refers us to the festive atmosphere of Sabantuy ("ә сөлгеләр - бизә кенә"), but rather functions as a metaphor. This is a reward to the winner of the combat "корәш"), evidence of his valour and courage ("сөлгеләр - батырлар өчен"). Embroidery on a towel is a manifestation of love and gratitude on the part of the embroiderer [Minңnullin, Karaқalpastan әхеңlere, p. 287].

The poem “Арал кызы Гөлайым” (“Gulayim, the Daughter of the Island") takes a special place in the cycle. It is an example of the poet's love lyrics and praises the beauty of a Karakalpak girl. Creating the portrait of a beautiful girl, the poet uses the potential of natural images: the girl's eyes are as blue as the waves of the Aral Sea, her gaze is radiant and gentle like the sun. At the end of the poem, the poet confesses his love for the girl Gulayim [Minңnullin, Karakalpak ahənnəre, p. 288].

The poem "Хушлашу сүзе" acts as a farewell word. The poet thanks the Karakalpak people for the warm welcome, for the preservation of friendship between fraternal peoples. The poet expresses the hope that the fruit of this cooperation is the creation of new songs that will glorify two peoples worthy of each other [Minłnullin, Кaraқalpastan әхеңlere, p. 289].

By the 70th anniversary of R. Minnullin, a number of his poems where he appears as a patriot were translated into the Karakalpak language. The translators were Saydin Amirlan [Minłnullin, Kosyklar, pp. 104-107], G. Esemuratov [Bərshe, bərshege! ], Kh. Ayimbetov [Ibid.].

\section{Results}

Our analysis of the works by the two contemporary poets T. Zhumamuratov and R. Minnullin, outstanding representatives of the Karakalpak and Tatar poetry of the second half of the twentieth century, testifies to stable creative contacts between the two fraternal peoples. The dialogue among cultures has been developed not only by common milestones in general Turkic history and translation activities, but also with some cultural events aimed at strengthening friendship between peoples. Motherland and the hymn to its sons were the leading themes in the work of the poets. Both poets rely on folklore images of Karakalpak and Tatar poetry. It is obvious that the writers are striving to find braces for maintaining friendly ties between the two fraternal peoples. T. Zhumamuratov and R. Minnullin are in awe of the power of the writer's word and the musical gift inherent in the Turkic peoples. The poets glorify their contemporaries, who embody the best qualities of their national character.

\section{Conclusions}

The dialogue between Karakalpak and Tatar cultures opens up the realms for a promising study 
that allows us to understand the features of the national literature development in a particular historical period, as well as to identify the two fraternal peoples' visions of the world. Tleubergen Zhumamuratov and Robert Minnulin made their worthy contribution to the strengthening of friendship between the peoples and to the development of the dialogue between Karakalpak and Tatar cultures.

\section{References}

Aral dulkynnary (1981) [Waves of the Aral Sea]. Tez. L. Khumidullin. 543 p. Kazan, Tatar.kit. nəshr. (In Tatar)

Okhmətжаnov, M. (2012). Tatars shəжərələre [Tatar Genealogies]. 1 t. 407 p. Kazan, Tatar. kit. nəshr. (In Tatar)

Omiȳdaria. (1981). No. 7, 120 p. (In Tatar)

Bekbergenova, Z. U. (2019). Tema Tatarstana v karakalpakskoi lirike [The Topic of Tatarstan in Karakalpak Lyrical Poetry]. Traditsionnaia kul'tura narodov Povolzh'ia: materialy V Vserossiiskoi nauchnoprakticheskoi konferentsii $\mathrm{s}$ mezhdunarodnym uchastiem, posviashchennoy 95-letiiu so dnia rozhdeniia izvestnogo etnografa R. G. Mukhamedovoi (12-14 fevralia 2019 g.). Kazan', Ikhlas, pp. 82-92. (In Russian)

Berdakh (1978). Dihgez balygyn birmade [The Sea Didn't Give Fish]. Sovet ədəbiiaty. No. 11, pp. 98-100. (In Tatar)

Barshe, barshege! (2018) [Hey, Everyone!]. Akmangyt taңy. No. 9 (4451), 31 mart, p. 3. (In Tatar)

Iashlegem - Chally. Shigyrlar (1979) [My Youth is Naberezhnye Chelny. Poems]. Tez. R. Lotfullin. 143 p. Kazan, Tatarstan kitap nashriiaty. (In Tatar)

Khabutdinova, M. M. (2018). Strana detstva Roberta Minnullina [The Country of Robert Minnullin's Childhood]. Dobryi mir Roberta Minnullina. Pp. 76-80. Kazan', Magarif-Vakyt. (In Russian)

Khabutdinova, M. M. (2008). Mir avtorskoi skazki Roberta Minnullina [The World of the Authorial Fairy Tale by Robert Minnullin]. Idel. No. 8, pp. 54-56. (In Russian)

Kudash, S. (1984). Stikhi i poemy [Verses and Poems]. 528 p. Ufa, Bashkirskoe knizhnoe izdatel'stvo. (In Russian)

Maksetov, K. M. (1987). Sviazi karakalpakskoi literatury s literaturami bratskikh narodov [Connections of Karakalpak Literature with Literatures of Fraternal Peoples]. 210 p. Nukus, Karakalpakstan. (In Russian)

Massetov, Қ. (1980). Tatar x̧əm қ̧araķalpaқ ədebiy bayanislary x̧akқynda [On Tatar and Karakalpak Literary Relations]. Omiȳdəria. No. 7, pp. 73-76. (In Tatar)

Məkъsytov, K. (1981). Bezga kech birgan duslyk [Friendship that Gave Us Strength]. Kazan utlary. No. 5, pp. 4-7. (In Tatar)

Minnegalieva, A. I., Mingazova, L. I., Dzhumamuratova, M. T. (2020). General Roots, General Spirituality: Literary Relationship of Tatar and
Karakalpak Literatures in the Aspect of the Dialogue of Cultures . Applied linguistics research journal. No. 4 (7), pp. 26-31. (In English)

Miңnullin, R. (2007). Karakalpak ahənnəre [Karakalpak Tunes]. Minnullin R. Osərlər 7 t., 1 t. Pp. 285-292. Kazan, Tatar. kit. nəshr. (In Tatar)

Miңnullin, R. (2019). Doslyk, tuyskanlyk kyzkynlary [Friendship and Kinship Interests]. Omidəria. No. 2, pp. 83-84. (In Tatar)

Miңnullin, R. (2019). Karagalpaқsstan ax̧ę̧leri [Songs of Karakalpakstan]. Đmiȳdəria. No. 2, pp. 8687. (In Tatar)

Miңnullin, R. (2018). Kosyķlar [Verses]. Omiȳdəria. No. 4, pp. 104-107. (In Tatar)

Pakhratdinov, Ә. (1997). Esigił̧niң̧ aldynan ақ̧қаn suỹdy қədiri zhok [The Water Flowing past Your Door Is Worthless]. Đmiȳdəria. No. 3-4, pp. 109-111. (In Tatar)

Sarchin, R. Sh. (2012). Mir poezii Roberta Minnullina [Robert Minnullin's World of Poetry]. 192 p. Kazan', Magarif-Vakyt. (In Russian)

Shaiyrlary Tatar (1980) [Tatar Verses]. 219 p. Nokis, Karakalpakstan. (In Karakalpak)

Tatarskie rasskazy (1980) [Tatar Stories]. 262 p. Nukus, Karakalpakstan. (In Russian)

Tatarstan Karakalpakstan adabiiat ham sangate kennore (1981) [The Days of Karakalpakstan Literature and Art in Tatarstan]. Kazan utlary. No. 5, pp. 3-59. (In Tatar)

Тоқаi, F. (1960). Shygarmalars [Verses]. 152 p. Nekis, Қаraқalpaқ mamleket baspasy. (In Karakalpak)

Zhalil, M. (1958). Zhyrlarym [My Songs]. 135 p. Nokis, Karagalpakstan. (In Tatar)

Zhumamuratov, T. (1986). "Diidar" by Sorā̄laryn zhuỹap ["Didar"Answers the Questions]. Zhas Leninshi. No. 78 (5828). (In Tatar)

Zhumamuratov, T. (2016). Aralga keldim oralyp [I Came Back to the Island]. 322 p. Nekis, Qaraqalpaqstan. (In Tatar)

Zhumamuratov, T. (2005). Өтінің̧niң өzi-filosofiia [Your Life Itself is a Philosophy]. 335 p. Nokis, Karaқalpakstan. (In Tatar)

Zhumamuratova, M. (2018). Madeniiatlar saȳbeti x̧əm zhakyn tillerden aȳdarma problemalary $(R$. Miłnullin poeziasyny karakalpaksha audarmalary mysalynda) [The Dialogue among Cultures and the Problems of Translation from Related Languages (based on the Karakalpak translations of R. Minnullin's poetry)]. Literatura i khudozhestvennaia kul'tura tiurkskikh narodov $\mathrm{v}$ kontekste Vostok-Zapad, posviashchennaia 70-letnemu iubileiu narodnogo poeta Respubliki Tatarstan Roberta Minnullina: sbornik materialov Mezhdunarodnoi nauchno-prakticheskoi konferentsii (11-18 oktiabria 2018 goda) pod red. F. S. Saifulinoi. Kazan, Artifakt, pp. 76-84. (In Tatar)

Zhumamuratova, M. (1981). "Kazireylini aldagan adam" karagalpak sakhnasynda ["The Man Who Deceived Azirielini" on the Karakalpak Stage]. Sovet Каraқalpaқstany. No. 60 (13229). (In Tatar) 
Zhumamuratova, M. (2015). Almalarza ķarap zhazylzan ķosyķlar [Poems Written on Apples]. Қагақаlрақstan zhaslary. 5 November. No. 44 (7853). (In Tatar)
Zhumamuratov, T. (2020). Iz materialov domashnego arkhiva poeta [From the Poet's Home Archive]. Rukopis', pp. 7-2. (In Russian)

Zhumamuratov, T. (1984). Talisman liubvi [The Talisman of Love]. 180 p. Nukus, Karakalpakstan. (In Russian)

\title{
ДИАЛОГ КАРАКАЛПАКСКОЙ И ТАТАРСКОЙ КУЛЬТУР В ТВОРЧЕСТВЕ ПОЭТОВ Т. ЖУМАМУРАТОВА И Р. МИННУЛЛИНА
}

\author{
Малика Тлеубергеновна Джумамуратова, \\ Каракалпакский государственный университет имени Бердаха, \\ Узбекистан, Республика Каракалпакстан, 230100, г. Нукус, ул. Ч. Абдирова, д. 1, \\ djuma2008@mail.ru.
}

\begin{abstract}
В статье систематизирован материал по истории литературных контактов каракалпакских и татарских поэтов. Доказано, что общее фольклорное достояние является фундаментом для литературных взаимосвязей двух братских народов. Одним из стимулов является устойчивый интерес читателей к каракалпакской и татарской литературе. Огромную роль в укреплении дружбы между народами играют переводы художественных произведений. Материалом исследования послужило творчество поэтов-современников Тлеубергена Жумамуратова (19151990) и Роберта Миннуллина (1948-2020). В статье выявлено своеобразие раскрытия татарской и каракалпакской тем в их наследии.
\end{abstract}

Ключевые слова: каракалпакская литература, татарская литература, литературные контакты, литературные взаимосвязи, диалог культур.

\section{Введение}

По мнению каракалпакского литературоведа Кабула Максетова, корни литературных взаимосвязей татарского и каракалпакского народов следует искать еще в глубокой древности, в общем фольклорном наследии [Мәкъсүтов, с. 4]. Лирон Хамидуллин в своей статье «Ерак аларны якып итеп...» («Сокращая дистанцию...») приводит яркие примеры, подтверждающие этот тезис ученых. Дух предков оживает в словах песни: «Идел - илнең ишеге, Жаек - жсирнең бишеге». - «Идель - ворота страны, Уральск - кольбель земли». Навсегда врезались в память братских народов строки из дастана «Идегей»: «Атам кияү булган ж⿻ир, Анам килен булган жсир, Кендегемне кискән жчир. Тәмле суын эчкән жсир». - «Это земля, где мой отеи стал мужем, / Это земля, где моя мать стала снохой, / Это земля, где обрезали мне пуповину, / Где испил я вкусной водыр».

Лирон Хамидуллин считает, что, помимо общего фольклорного наследия, двух братских народов сближает общая история, уходящая своими корнями в эпоху Золотой Орды. На это в своих трудах обратил внимание татарский этнограф Марсель Ахметзянов [Татарстанда Каракалпакстан әдәбият һәм сәнгате көннәре, с. 55].

Еще одним стимулом для развития взаимосвязей явился устойчивый интерес каракалпакских читателей к татарской литературе. Благодаря татарским газетам, выходившим в Казани, Уфе, Оренбурге, стихотворения Габдуллы Тукая еще до революции быстро обрели популярность в Центральной Азии, и поэт превратился в общее достояние тюркских народов.

Каракалпакские писатели познакомились с жемчужинами русской и зарубежной литературы в начале XX века благодаря татарскому языку и через татарскую литературу. Стихотворения Г. Тукая, Дэрдменда, С. Рамиева нашли свой отклик в душе каракалпакского читателя. Через творчество этих поэтов в каракалпакскую литературу проникла идея синтеза Востока и Запада [Minnegalieva, Mingazova, Djumamuratova, c. 26].

Л. Хамидуллин отмечает, что татарские читатели проявляют интерес к творчеству каракалпакских чиченов. Так, к 150-летию поэта 
Бердаха (1827-1900) переводчица Бика Рахимова перевела несколько его стихотворений на татарский язык [Бердах]. С удовлетворением татарский писатель пишет о том, что на родине поэта идет огромная работа по увековечиванию его памяти [Татарстанда Каракалпакстан әдәбият һәм сәнгате көннәре, с. 56].

Огромную роль в укреплении литературных взаимосвязей сыграли переводы произведений татарских и каракалпакских писателей. Так, стихотворения Г. Тукая были переведены на каракалпакский язык только после революции. Настоящим культурным событием в жизни республики, по мнению К. Максетова, стало издание в 1960 году сборника стихотворений Г. Тукая. Каракалпакские поэты-переводчики Б. Исмаилов, О. Хожаниязов, И. Юсупов перевели около 90 произведений великого татарского поэта [Мәкъсүтов, с. 4]. И. Юсупов в своей вступительной статье к сборнику признается, что считает себя учеником Г. Тукая, «солнца татарской поэзии». Впервые поэт познакомился с творчеством татарского поэта благодаря сборнику стихотворений, выпущенному в 1938 году, чьим редактором был М. Джалиль [Тоқай, с. 6].

К. Максетов отмечает, что Г. Тукай сыграл огромную роль в формировании личности писателя Сейфулгабита Мажитова, уроженца Казанской губернии, волею судьбы оказавшегося в среде каракалпакского народа. Здесь он снискал не только литературную славу, но и обрел известность как просветитель, разработчик учебников и учебной литературы для каракалпакских школ. Известно, что С. Мажитов был близко знаком с творчеством $Г$. Тукая, Ф. Амирхана, К. Насыри, Г. Камала, Г. Ибрагимова, Г. Кулахметова, Ш. Камала, М. Гафури. Большой вклад внес писатель в становление и развитие национальной драматургии и театра [Мәкъсүтов, с. 4]. Л. Хамидуллин подчеркивает роль уроженца Казанской губернии в становлении национальной прессы. С. Мажитов сначала выпускал рукописный журнал «Кызыл мөгаллим» («Красный учитель»), позднее в 1931 году создал литературный журнал «Хезмәт әдәбияты» («Литература труда») [Татарстанда Каракалпакстан әдәбият hәм сәнгате көннәре, б. 58].

Показательно, что первый самодеятельный театральный кружок в 1919-1920 гг. появился на свет благодаря уроженцу Казани Касиму Ямашеву. Репертуар кружка состоял из пьес татарских драматургов М. Файзи («Галиябану»),
К. Тинчурина («Казанское полотенце», «Голубая шаль»), Х. Ибрагимова («Башмачки»). Это послужило толчком для создания профессиональной театральной труппы, которая была вскоре сформирована из студентов педагогического техникума в Турткулле. Ею руководил Зариф Касыймов [Мәкъсүтов, с. 4].

Большим культурным событием в республике стало издание в 1958 году сборника стихов Мусы Джалиля «Жырларым («Моабит дәптеринен») в переводе на каракалпакский язык с предисловием Т. Жумамуратова. В книге значительная часть переводов принадлежит Т. Жумамуратову и О. Хожаниязову, также есть переводы М. Касымова, Х. Тажимуратова, К. Досанова [Жалил].

Заметный след в истории дружбы двух братских народов оставили Дни литературы и искусства. В памяти писателей до сих пор сохраняются трепетные воспоминания о Днях литературы и искусства ТАССР в Каракалпакстане, которые состоялись 20-25 августа 1980 года. По единодушному мнению литературоведов, это мероприятие открыло новую страницу в истории диалога культур каракалпакского и татарского народов. В рамках этого масштабного культурного мероприятия увидели свет сборники «Татарские рассказы» (1980) [Татарские рассказы], «Поэты Татарстана» (1980) [Татар шайырлары], тематический номер журнала «Әмиўдәрья» [Әмиўдәрья], в котором были опубликованы переводы произведений татарских поэтов и прозаиков (1981). Каракалпакский читатель получил возможность близко познакомиться с творчеством таких татарских поэтов, как С. Хаким, Х. Туфан, А. Ерикей, Ш. Галиев, 3. Нури, Ф. Карим, С. Сулейманова, И. Баянов, Р. Файзуллин, И. Юзеев, А. Исхак, Зульфат, Г. Рахим, Р. Харис, Р. Миннуллин, Р. Гатауллин, а также с прозой Г. Ахунова [Әмиўдәрья].

В 1980 году в Каракалпакском государственном театре была поставлена пьеса знаменитого татарского драматурга Туфана Миннуллинна «Әлдермештен Әлмендер» (режиссер К. Абдреимова). Спектакль был тепло принят каракалпакскими зрителями [Жумамуратова, 1981, с. 4].

В 1981 году ТАССР принимала у себя гостей из братской республики. Вышел в свет специальный номер журнала «Казан утлары» («Огни Казани») [Татарстанда Каракалпакстан әдәбият һәм сәнгате көннәре]. Накануне Дней литературы и искусства каракалпакского наро- 
да в Татарстане была выпущена антология поэтических и прозаических произведений каракалпакских писателей «Арал дулкынннары» («Волны Арала»), составителем сборника является Лирон Хамидуллин [Арал дулкыннары].

Благодаря Л. Хамидуллину, татарский читатель на страницах журнала «Казан утлары» («Огни Казани») в 1981 году получил редкую возможность совершить краткий экскурс в историю становления советской каракалпакской литературы [Татарстанда Каракалпакстан әдәбият һәм сәнгате көннәре, с. 55-59].

Эти культурные мероприятия нашли отражение в творчестве писателей. Перу Роберта Миннуллина принадлежит цикл стихотворений «Қарақалпақстан әхеңлери», посвященных Каракалпакстану [Минңнуллин, Қарақалпақстан әхеңлери, с. 8-13]. Тлеуберген Жумамуратов увековечил свои впечатления от поездки в Казань в своем стихотворении «Казан шэхэри» [Жумамуратов, 2005, с. 226].

Тема культурных и литературных взаимосвязей Татарстана и Каракалпакстана не раз привлекала к себе внимание и ученых ([Максетов], [Бекбергенова], [Minnegalieva, Mingazova, Djumamuratova], [Жумамуратова, 2018] и др.). Изучение феномена, получившего название «диалог культур», не предполагает оценку определенной культуры, а ставит целью выявление особенностей и своеобразия национальных культур путем их сопоставления и ознакомления с уникальностью каждой культуры. Внедрение роли диалога как ценности, направляющей мир к благородным начинаниям, помогает расширению духовно-нравственного эстетического опыта.

Предметом исследования в нашей статье стал диалог каракалпакской и татарской культур в творчестве поэтов Тлеубергена Жумамуратова (1915-1990) и Роберта Миннуллина (1948-2020).

\section{Материал и методы исследования}

Материалом исследования послужили произведения Т. Жумамуратова и Р. Миннулина, в которых встречаются татарская и каракалпакские темы. Изучение этих источников позволяет нам выявить характер литературнокультурных взаимосвязей между татарскими и каракалпакскими писателями во второй половине XX века.

Наше исследование базируется на принципах системно-целостного анализа художественной структуры произведения, сочетающего элементы исторического и сравнительносопоставительного методов исследования.

\section{Обсуждение}

Тлеуберген Жумамуратов и Роберт Миннуллин - яркие представители национальной литературы XX века.

Тлеуберген Жумамуратов (1915-1990) - народный поэт Каракалпакстана (1967), народный поэт Узбекистана (1969), лауреат государственной премии имени Бердаха, награжденный орденами «Дружба народов», «Знак Почета». T. Жумамуратов - поэт-импровизатор, лирик, философ, мастер сатиры и юмора, знаток истории, литературы, переводчик, драматург, публицист. О его энциклопедических знаниях в области языка, истории и искусства говорится в ряде научных работ [Пахратдинов, с. 111].

Роберт Миннуллин (1948-2020) - известный татарский писатель, общественный деятель, политик, заслуженный деятель искусств PТ, заслуженный работник культуры Башкортостана, лауреат Государственной премии РТ им. Г. Тукая, им. М. Джалиля, им. А. Алиша, международной литературной премии имени Г. Х. Андерсена, Государственной премии Республики Башкортостана имени М. Карима ([Сарчин], [Хабутдинова, 2008], [Хабутдинова, 2018] и др.).

T. Жумамуратов от прославленных сказителей прошлого унаследовал редкий дар импровизатора. Поэт сохранял традиции народного фольклора в современности. Слава о нем и его поэтическом мастерстве («айтыс») начиная с юности гремела на родине и далеко за пределами родного края. Поэту-оратору была присуща своеобразная исполнительская манера выразительного чтения. Т. Жумамуратов читал наизусть даже свои крупные произведения. Это было новое явление в национальной литератуpe.

T. Жумамуратов - уроженец Муйнака, дитя Аральского моря, где провели свою жизнь великие поэты-классики, такие как Кунходжа, Ажинияз, Бердах, Аяпберген, чей поэтический талант был тесно связан с искусством «баксы» - певцов, «жырау» - сказителей, «кыссаханов» - чтецов народных книг певчим голосом, мастеров «айтыс» - острословов. Сказитель Аяпберген был наставником Тлеубергена [Жумамуратов, 1986, с. 3], от него он принял народную эстафету, что соответствовало национальной поэтической традиции. 
Благодаря феноменальной памяти, Т. Жумамуратов занимался сбором и публикацией культурного наследия прошлого. Поэт был большим знатоком и неутомимым пропагандистом творчества своих наставников. Т. Жумамуратов помог фольклористам восстановить жемчужины народной поэзии. Он был автором критических статей, посвященных проблеме сохранения и публикации оригинальных вариантов поэтического наследия. Поэт искусно играл на дутаре.

В основе его художественного мышления идея дружбы, диалога культур [Максетов, 1987, c. 141]. В своем программном стихотворении поэт так утверждает ценности мира и дружбы между народами:

«Эх, люди, люди! Вы понять должны,

Что лишь для мира создан человек.

Забыли разве, что и без войны

Отпущен человеку краткий век» [Жумамуратов, 1984, с. 22] (перевод А. Каныкина).

«Мир изначально сотворен для всех!», - таков лозунг каракалпакского поэта [Жумамуратов, 2016, б.18]

Тема дружбы между татарским и каракалпакским народами впервые в творчестве T. Жумамуратова прозвучала в стихотворении «Казан шәхәри» («Город Казань»):

\begin{tabular}{|l|l|}
\hline «Сиз бенен бир тәғдир & С вами одна судьба и \\
менен арымыз, & достоинство, \\
Биз айтамыз тиллеримиз & Мы говорим, что у нас \\
ортақ деп, & общий язык, \\
Бизлер Әмиудәрья татар- & Мы - Татары Амударьи, \\
ларымыз, & Татар считаем своими \\
Татарды да билдик & каракалпаками \\
қарақалпақ деп» [Жума- & (здесь и далее подстр. \\
муратов, 2005, с. 226-- & перевод наш - М. Д.). \\
227]. & \\
\hline
\end{tabular}

Через этноним «татары» поэт восстанавливает вековые корни дружбы между двумя братскими народами. «В средние века предки современных каракалпаков и татар были тесно связаны этнически, политически, экономически и в культурном плане. Это явление <..> сохранилось в родословных этих двух родственных народов. К примеру, считается, что в древние времена во главе каракалпакских племен-родов в родословной стоит имя Майкы би», - делится своими наблюдениями в книге «Татар шәжәрәләре» («Татарские шажаре») M. Ахметзянов [Әхмәтжанов, с. 29].
Взор поэта устремлен в седую старину, когда предки каракалпаков в ранний исторический период также населяли берега Едиля (Волги) и Жайыка (Урала), но, подвергаясь постоянным вражеским набегам, вынуждены были разбредаться по миру: «Едил қайда, ел қайда» (то есть «где Волга, а где родина моя»). Поэт в своем стихотворении тоскует по исторической родине, выражает чаяния своего кочевого народа.

T. Жумамуратов отмечает, что его представление о татарской столице сформировалось на основе творчества древних сказителей:

\begin{tabular}{|l|l|}
\hline «Жас күнимнен & Живет с молодых лет в \\
қатеремде сақлаўлы, & памяти моей, \\
Еситкеним & То, что слышал от рас- \\
жыршылардың жырынан, & сказов сказителей. \\
Шәхәрсең сен ел аўзында & Город ты хваленный на- \\
мақтаўлы, & родом, \\
Тарийхларға гүўа болған & Свидетель истории древ- \\
бурыннан» & них времен. \\
[Жумамуратов, 2005, с. & \\
226]. & \\
\hline
\end{tabular}

Казань для поэта - город, который связан с именами великих классиков русской и татарской литературы: А. С. Пушкина, Г. Тукая и М. Горького. Как известно, в становлении поэта огромную роль сыграло творчество татарского поэта Габдуллы Тукая [Minnegalieva, Mingazova, Djumamuratova, c. 26]. Благодаря татарским переводам, каракалпакский поэт в свое время познакомился с творчеством классиков русской и мировой литературы, что нашло отражение в анализируемом стихотворении:

\begin{tabular}{|l|l|}
\hline «,Едил бойы - ескилик- & Говорят, «Берега Едила - \\
ли ел“- - дейди, & старинные народы», \\
Қәсийетли сыпатының & Широки волшебные ка- \\
түри кең, & чества в нем. \\
Ата-бабам Пушкин ме- & Пушкина и Горького, \\
нен Горькийди, & предки мои - \\
Үйренипти уллы Тоқай & Изучали на языке Вели- \\
тилинен» & кого Тукая. \\
[Жумамуратов, 2005, с. & (подстрочный перевод). \\
$226]$. &
\end{tabular}

Изучая воспоминания о Т. Жумамуратове, мы обнаружили показательный диалог отца и дочери, состоявшийся после его поездки в Казань: 
«- Папа, папа, город Казань, это большой казан? Из самолета вы сразу соскользнули в большой казан? Вас варили? Кипятили?

- Нет, доченька! Казань - город, где кипит поэзия! Я сочинил „Едил бойы - ескиликли ел дейди, Қәсийетли сыпатының түри көп“" и пошел дальше!.. Сочинять много!» [Жумамуратова, 2015, с. 3].

Таким образом, в творческом сознании каракалпакского поэта татарская столица приобретает поэтические очертания. Для Т. Жумамуратова татарская столица - казан поэзи и, средоточие творческой энергии.

Архив писателя свидетельствует о тесных контактах каракалпакского писателя с татарскими собратьями по перу. Так, например, здесь хранится Благодарственное письмо Татарского книжного издательства, знак признательности заслуг писателя на ниве переводческой деятельности в деле пропаганды творчества каракалпакских и татарских поэтов [Жумамуратов, 2020].

В библиотеке Т. Жумамуратова бережно хранятся книги татарских писателей, в частности сборник татарских стихов «Яшьлегем - Чаллы» («Юность - Набережные Челны»). Составитель сборника - Равиль Лотфуллин. Весьма показательной является дарственная надпись на книге: «Выдающемуся народному поэту Отчизны, поэту-философу, поэтугражданину, прекрасному человеку и замечательному певцу дружбы и братства народов, славному сыну и одному из аксакалов нашего верного друга - каракалпакского народа Тлеуберген ага Жумамуратову - чей природный талант и прекрасные произведения служат примером беззаветного служения Родине с самыми наилучшими пожеланиями и уважением, Челнинские писатели. Июнь, 1981» [Яшьлегем - Чаллы, 1979]. Так, сборник стихотворений Сайфи Кудаша был подарен автором каракалпакскому поэту на семидесятилетие с автографом [Кудаш]. Письма, поздравительные телеграммы и открытки - еще одно свидетельство тесных контактов Т. Жумамуратова с татарскими писателями.

Наше внимание привлекла поэма Т. Жумамуратова «Среди океана» (1969-1971) [Жумамуратов, 1986, с. 13], в которой поэт воспевает подвиг татарского паренька Аската. Сюжет произведения основан на реальных событиях. Внимание поэта привлекла история чудесного спасения баржи и четырех моряков на простоpax Тихого океана.
Поэма состоит из четырех частей. Ее хронотоп вбирает в себя не только морскую стихию, но и железнодорожную станцию Шентала, расположенную в российской глубинке, в Самарской области.

Поэт умело использует в поэме прием контраста. Вначале Т. Жумамуратов воспевает величественную красоту океана. Безбрежность океана у поэта ассоциируется с безграничностью человеческой души. «Вальс распевный» накрывает Тихий океан и оказывается под стать мертвому штилю, царящему вокруг. Однако внезапно возникший ураган разрушает эту идиллическую гармонию человека и природы.

Автор поэмы воспевает мужество моряков баржи, оказавшейся во власти шторма. Поэт восхищается героизмом татарина Аската, в критической ситуации взявшего в свои руки управление баржей, сорвавшейся с якоря. Ключевым для характеристики героев становится высказывание Аската: «Mbl, ребята, не трава, / Что под ветром гнется» [Жумамуратов, 1984, c. 18]. За время скитаний в открытом океане моряки пережили голод и холод, не раз смотрели в лицо смерти.

T. Жумамуратов прибегает к романтическим краскам при описании битвы человека со стихией. Поэт склоняет голову перед подвигом четырех моряков-храбрецов, представителей разных народов. Среди них Т. Жумамуратов выделяет моряка-татарина, от грамотных действий которого зависит судьба экипажа и баржи. Герой из схватки со стихией выходит победителем.

Вторая сюжетная линия в поэме позволяет читателям понять истоки мужества Аската. Поэт знакомит нас с историей преданной любви моряка и Насимы. Именно любовь к родным и любимой девушке позволила татарскому парню выстоять в самые страшные минуты шторма. Поэт воспевает чуткость и преданность Насимы, вместе с родителями Аската пережившей страшный период, когда от моряков не было никаких вестей. Т. Жумамуратов прибегает к приему параллелизма при изображении жизни Насимы. Поэт вновь эксплуатирует мотив преодоления жизненных трудностей. Девушка, чтобы узнать о судьбе любимого, в зимнюю непогоду преодолевает огромный путь. Примечательно, что поэт при создании мужественных образов влюбленных целиком опирается на потенциал народной поэзии. Это проявляется особенно ярко на уровне портретной характеристики («девушка-тростиночка»). В поэме 
важное место отводится мотиву вещего сна. Девушка верит в счастливый исход событий. На родину моряки возвращаются героями. Аската встречает отец, Рахимзян абый, исполненый гордости за сына. Поэма Т. Жумамуратова превратилась в настоящий гимн человеку, одолевшему стихию.

Таким образом, Т. Жумамуратов в своем творчестве воспел не только татарскую землю, но и ярких представителей татарского народа. Все это свидетельствует об уважительном отношении писателя к братскому народу и его культуре.

Со столь же трепетным отношением мы сталкиваемся и во время знакомства с циклом стихотворений татарского поэта Р. Миннуллина «Каракалпак аһәннәре» («Каракалпакские мелодии»), созданных под впечатлением Дней литературы и искусства в Татарстане и Каракалпакстане. В 2019 году этот цикл был переведен на каракалпакский язык поэтом Медраилом Турынмуратовым [Миннуллин, 2007, с. 85-88]. Татарский писатель с огромной теплотой в предисловии к своим переводам вспоминает о путешествии татарской делегации по Каракалпакстану (1980) [Миннуллин, 2019]. Цикл состоит из 5 стихотворений. Открывается он стихотворением «Үс син, чәчәк! » («Расти ты, цветок!»), где, как и у Т. Жумамуратова, ведущим становится мотив преодоления жизненных трудностей. Любуясь цветком, выросшим на раскаленной почве, поэт размышляет о жизненном потенциале человека, волей судьбы вынужденного жить в таких суровых природных условиях. Р. Миннуллин приходит к выводу:

\begin{tabular}{|l|l}
\hline «Үс син, чәчәк, & Расти ты, цветок, \\
Чүл - үзеңнең & Пустыня - твоя \\
Туган жирең бит» & Ведь родная земля. \\
[Миңнуллин, Каракалпак & \\
ahәннәре, с. 285]. & \\
\hline
\end{tabular}

В результате стихотворение превращается в гимн преданной любви к родине. Для татарского поэта каракалпакская земля, овеваемая раскаленным ветрами, олицетворяет вечность и символизирует вековую укорененность человека на родной земле.

Мелодия дружеского дутара в стихотворении «Уйна, дутар!» («Играй, дутар») соединяет берега Амударьи с Волгой. Она превращается в зримое напоминание об общетюрском единстве культуры. Каракалпакская песня разливается под небом Татарстана, напоминая о вековой дружбе между двумя братскими народами [Миңнуллин, Каракалпак аһәннәре, с. 286].

Р. Миннуллин испытывает огромную радость, когда на Сабантуй приезжают борцы из Каракалпакстана («Кунак егетләр» («Парнигости»)). Поэт искренне гордится национальной борьбой. Он безмерно рад, что гости попробуют себя в татарской борьбе. Образ белого вышитого полотенца в стихотворении выступает не столько в качестве предметной детали, отсылающей нас к праздничной атмосфере Сaбантуя («ә сөлгеләр - бизә кенә»), сколько обладает метафорическим содержанием. Это награда победителю в борьбе («корәш»), свидетельство его доблести и мужества («сөлгеләр - батырлар өчен»). Вышивка на полотенце есть проявление и выражение любви и признательности со стороны вышивальщицы [Там же, с. 287].

Особое место в цикле занимает стихотворение «Арал кызы Гөлайым», которое является образцом любовной лирики поэта. В нем воспевается красота каракалпакской девушки. Создавая портрет красавицы, поэт использует потенциал природных образов: глаза девушки голубые, как волны Аральского моря, взор лучистый и нежный, подобно солнцу. В конце стихотворения поэт признается в любви к девушке Гөлайым [Там же, с. 288].

Стихотворение «Хушлашу сүзе» носит характер прощального слова. Поэт благодарит каракалпакский народ за теплый прием, за сохранение дружбы между братскими народами. Поэт выражает надежду, что плодом этого сотрудничества становится создание новых песен, которые прославят два народа, которые достойны друг друга [Там же, с. 289].

К 70-летию Р. Миннуллина на каракалпакский язык был переведен ряд его стихотворений, где он предстает как поэт-патриот. Огромный вклад в популяризацию творчества татарского писателя внесли переводчики Сайдин Амирлан [Миннуллин. Косықлар, с. 104-107], Г. Есемуратов [Бәрше, бәршеге!], Х. Айымбетов [Там же].

\section{Результаты}

Анализ творчества двух поэтовсовременников Т. Жумамуратова и Р. Миннуллина, ярких представителей каракалпакской и татарской поэзии второй половины XX века, свидетельствует об устойчивых творческих контактах между двумя братскими народами. 
Питательной почвой для диалога культур послужили не только общие вехи общетюркской истории, переводческая деятельность, но и культурные мероприятия, нацеленные на укрепление дружбы между народами. Ведущими темами в творчестве поэтов стали тема родины и гимн сынам родной земли. При создании стихотворений оба поэта опираются на фольклорные образы каракалпакской и татарской поэзии. Очевидно стремление писателей обрести скрепы для поддержания дружеских связей двух братских народов. Т. Жумамуратов и Р. Миннуллин благоговеют перед силой писательского слова и музыкального дара, свойственного тюркским народам. Поэты воспевают своих современников, воплощающих лучшие качества национального характера.

\section{Выводы}

Изучение диалога культур каракалпакского и татарского народов является перспективным исследованием, которое позволяет нам понять особенности развития национальной литературы в тот или иной период исторического развития, выявить национальные образы мира двух братских народов. Тлеуберген Жумамуратов и Роберт Миннулин внесли достойный вклад в укрепление дружбы между народами и в развитие диалога культур между каракалпакским и татарским народами.

\section{Литература}

Бекбергенова 3. У. Тема Татарстана в каракалпакской лирике // Традиционная культура народов Поволжья: материалы V Всероссийской научно-практической конференции с международным участием, посвященной 95-летию со дня рождения известного этнографа Р. Г. Мухамедовой (12-14 февраля 2019 г.). Казань: Ихлас, 2019. С. 82-92.

Жумамуратов $T$. Из материалов домашнего архива поэта. Рукопись 2020. С. 7-2.

Жумамуратов T. Талисман любви. Нукус: Каракалпакстан, 1984. 180 с.

Кудаш С. Стихи и поэмы. Уфа: Башкирское книжное издательство, 1984. 528 с.

Максетов К. М. Связи каракалпакской литературы с литературами братских народов. Нукус: Каракалпакстан, $1987.210 \mathrm{c}$.

Татарские рассказы. Нукус: Каракалпакстан, 1980. $262 \mathrm{c}$.

Сарчин Р. Ш. Мир поэзии Роберта Миннуллина. Казань: Магариф-Вакыт, 2012. 192 с.

Хабутдинова М. М. Страна детства Роберта Миннуллина // Добрый мир Роберта Миннуллина. Казань: Магариф-Вакыт, 2018. С. 76-80.
Хабутдинова М. М. Мир авторской сказки Роберта Миннуллина // Идел. 2008. № 8. С. 54-56.

Арал дулкыннары / төз. Л. Хәмидуллин. Казан: Татар. кит. нәшр., 1981, 543 б.

Әхмәтж⿻анов $M$. Татар шәжәрәләре. 1 т. Казан: Татар. кит. нәшр., 2012. 407 б.

Мәкъсүтов К. Безгә көч биргән дуслык // Казан утлары. 1981. № 5. Б. 4-7.

Миннуллин Р. Каракалпак аһәннәре // Миннуллин Р. Әсәрләр 7 т.: 1 т. Казан: Татар. кит. нәшр., 2007. Б. 285-292.

Татарстанда Каракалпакстан әдәбият һәм сәнгате көннәре // Казан утлары. 1981. № 5. Б. 3-59.

Яшьлегем - Чаллы. Шигырьләр / төз. Р. Лотфуллин. Казан: Татарстан китап нәшрияты, 1979. 143 б.

Әмиўдәрья. 1981. №7. 120 Б.

Бәрше, бәршеге! // Акмангыт таңы. 2018. № 9 (4451) 31 март. Б. 3.

Бердаx. Диңгез балыгын бирмәде // Совет әдәбияты. 1978. № 11. Б. 98-100.

Жалил М. Жырларым. Нөкис: Қарақалпақстан, $1958.135 \mathrm{c}$.

Жумамуратов T. «Дийдар» сораууларына жуӯап // Жас Ленинши. 1986. № 78 (5828).

Жумамуратов T. Аралға келдим оралып. Нөкис: Qaraqalpaqstan, 2016. 322 б.

Жумамуратов T. Өмириңниң өзи - философия. Нөкис: Қарақалпақстан, 2005. 335c.

Жумамуратова М. Мәдениятлар сәӯбети хәм жақын тиллерден аўдарма проблемалары (P. Миңнуллин поэзиясының каракалпакша аудармалары мысалында) // Литература и художественная культура тюркских народов в контексте Восток-Запад, посвященная 70-летнему юбилею народного поэта Республики Татарстан Роберта Миннуллина: сборник материалов Международной научнопрактической конференции (11-18 октября 2018 года) / под ред. Ф. С. Сайфулиной. Казань: Артифакт, 2018. С. 76-84.

Жумамуратова М. «Әзирейлини алдаған адам» қарақалпақ сахнасында // Совет Қарақалпақстаны. 1981. № 60 (13229).

Жумамуратова М. Алмаларға қарап жазылған қосықлар // Қарақалпақстан жаслары. 2015. 5 ноябрь. № 44 (7853).

Мақсетов Қ. Татар хәм қарақалпақ әдебий байланыслары хаққында // Әмиўдәрья. 1980. № 7. Б. 73-76.

Миннуллин P. Дослық, туўысқанлық қызғынлары // Әмиўдәрья. 2019. № 2. Б. 83-84.

Миннуллин P. Қарақалпақстан әхеңлери // Әмиўдәрья. 2019. №2. Б. 86-87.

Миннуллин Р. Косықлар // Әмиӯдәрья. 2018. №4. б. 104-107

Пахратдинов Ә. Есигиңниң алдынан аққан суӯдың қәдири жоқ // Әмиўдәрья. 1997. №3-4. Б. 109-111. 
Татар шайырлары. Нөкис: Қарақалпақстан, 1980. 219 б.

Тоқ̧ай F. Шығармалары. Нөкис: Қарақалпақ мамлекет баспасы. 1960. 152 б.

Minnegalieva A. I., Mingazova L. I., Djumamuratova M. T. General Roots, General Spiritual- ity: Literary Relationship of Tatar and Karakalpak Literatures in The Aspect of The Dialogue of Cultures // Applied linguistics research journal. 2020. 4 (7). S. 2631.

\title{
ШАГЫЙРЬЛӘР Т. ЖУМАМОРАТОВ ҺӘМ Р. МИННУЛЛИН ИЖАТЫНДА КАРАКАЛПАК ҺӘМ ТАТАР МӘДӘНИЯТЛӘРЕ АРАСЫНДАГЫ ДИАЛОГ
}

\author{
Мәликә Теләүбиргән кызы Жумаморатова, \\ Бердах исем. Каракалпак дәүләт университеты, \\ Үзбәкстан, Каракалпакстан Республикасы, 230100, Нөкис ш., Ч. Абдиров ур., 1 нче йорт, \\ djuma2008@mail.ru.
}

\begin{abstract}
Мәкаләдә каракалпак һәм татар шагыйрьләре арасындагы әдәби бәйләнешләр тарихы буенча материал системалаштырыла. Ике тугандаш халыкның әдәби багланышлары өчен гомуми фольклор байлыгының нигез булып торуы дәлилләнә. Шулай ук укучыларның каракалпак hәм татар халыклары әдәбияты белән ныклы кызыксынуы этәргечләрнең берсе хезмәтен үти. Халыклар арасындагы дуслыкның ныгуында әдәби тәржемәләр гаять зур роль уйный. Тикшеренү өчен материал булып замандаш шагыйрьләр Теләүбиргән Жумаморатов (1915-1990) hәм Роберт Миңнуллин (1948-2020) ижатлары хезмәт итә. Мәкаләдә әлеге шагыйрьләр ижатында татар һәм каракалпак темаларының үзенчәлекле яктыртылуы ачыклана.
\end{abstract}

Төп төшенчәләр: каракалпак әдәбияты, татар әдәбияты, әдәби бәйләнешләр, мәдәниятләр арасындагы диалог. 